\title{
BMJ Open Prevalence of rheumatoid arthritis in relation to serum cadmium concentrations: cross-sectional study using Korean National Health and Nutrition Examination Survey (KNHANES) data
}

Sang Hyun Joo, ${ }^{1}$ Joongyub Lee, ${ }^{2}$ David Hutchinson, ${ }^{3,4}$ Yeong Wook Song ${ }^{1,5}$

To cite: Joo SH, Lee J, Hutchinson D, et al. Prevalence of rheumatoid arthritis in relation to serum cadmium concentrations: cross-sectional study using Korean National Health and Nutrition Examination Survey (KNHANES) data. BMJ Open 2018;9:e023233. doi:10.1136/ bmjopen-2018-023233

- Prepublication history for this paper is available online To view these files, please visit the journal online (http://dx.doi org/10.1136/bmjopen-2018023233).

Received 27 March 2018 Revised 18 0ctober 2018 Accepted 8 November 2018

Check for updates

(C) Author(s) (or their employer(s)) 2018. Re-use permitted under CC BY-NC. No commercial re-use. See rights and permissions. Published by BMJ.

For numbered affiliations see end of article.

Correspondence to Dr Yeong Wook Song; ysong@snu.ac.kr

\section{ABSTRACT}

Objectives It has been suggested that exposure to heavy metal cadmium (Cd) may contribute to a high risk of developing rheumatoid arthritis (RA). This study was to investigate the association of RA prevalence and serum concentrations of $\mathrm{Cd}$ and other heavy metals through large survey data analysis.

Design A retrospective cross-sectional survey study.

Setting Large population survey in Korea.

Participants 53829 subjects participated in Korean National Health and Nutrition Examination Survey (KNHANES) from 2008 to 2013.

Interventions Heavy metals were measured in different time periods of the survey programme which resulted in three different data sets for analysis: $\mathrm{Cd}$, mercury $(\mathrm{Hg})$ and lead $(\mathrm{Pb})$ from 2008 to 2012 survey; serum manganese (Mn) and urine arsenic (As) from 2008 to 2009 survey; and serum zinc (Zn) from 2010 survey. RA prevalence and its associations with serum heavy metals were analysed using a general linear/ logistic regression model of complex sample design.

Results Serum Cd was elevated in patients with RA (RA vs control: $1.30 \pm 0.07 \mu \mathrm{g} / \mathrm{L}$ vs $1.17 \pm 0.01 \mu \mathrm{g} / \mathrm{L}, \mathrm{p}<0.01$ ). There were no significant differences in urine levels of As or serum levels of $\mathrm{Pb}, \mathrm{Hg}, \mathrm{Mn}$ or $\mathrm{Zn}$ between patients with $\mathrm{RA}$ and controls. OR $(95 \% \mathrm{Cl})$ of RA prevalence according to $1 \mu \mathrm{g} / \mathrm{L}$ increase of serum Cd level was $1.28(95 \% \mathrm{Cl} 1.03$ to 1.61$)$. Prevalence of RA in women was increased with increasing quartiles of $\mathrm{Cd}$ levels, with a 19-fold difference in female RA prevalence between individuals in the lowest quartile of serum Cd level and those in the highest quartile $(0.18 \%$ vs $3.42 \%)$.

Cubic spline curve of prevalence OR showed increased risk of RA according to increased serum Cd level. Increased risk of RA in men was not observed with increased serum Cd levels. Conclusion There was an increased prevalence of RA in females associated with increased serum levels of $\mathrm{Cd}$ in the Korean population.

\section{INTRODUCTION}

Rheumatoid arthritis (RA) is an autoimmune inflammatory disease with an estimated global prevalence of $0.3 \%-1.0 \% .^{1}$ Due to
Strengths and limitations of this study

- The largest study to date of serum and urinary heavy metal concentrations in a cohort of patients with rheumatoid arthritis (RA) and healthy controls.

- The analysis for the first time of heavy metal levels and RA prevalence included important socioeconomic parameters relevant to heavy metal exposure and corrected for these factors in the cohorts studied.

- Detailed clinical characteristics of patients with RA such as rheumatoid factor, anti-cyclic citrullinated peptide antibody and disease activity were unavailable.

- This study as with any cross-sectional study may have potential unknown inherent biases and confounding factors.

joint inflammation and subsequent development of joint deformities, individuals with RA may experience impaired physical function, fatigue, reduced quality of life, reduced employment and decreased work productivity. ${ }^{2}$ The overall economic cost of RA to society is substantial. One study has highlighted that RA is one of the five most costly musculoskeletal diseases in Korea. ${ }^{3}$ Therefore, studies identifying potential avoidable causes of RA are critically important both to at-risk individuals and the wider society.

Cadmium $(\mathrm{Cd})$ is a ubiquitous environmental pollutant. It has been suggested that Cd may contribute to a high risk of developing RA through cigarette smoking, various occupational inhalational exposures relevant to both genders and residing within close proximity to roadside dusts and fumes. ${ }^{4-7}$ However, whether Cd exposure could potentially influence the outcome of RA remains 
controversial. Two recent animal studies have suggested that low doses of $\mathrm{Cd}$ might have beneficial effect on joint inflammation. ${ }^{8}$ However, Cd at higher doses exacerbates joint inflammation. ${ }^{8}$ Smoking is associated with significantly increased blood Cd levels. Cd is considered the standout metal of all metals contained within cigarette smoke in terms of increased blood levels in smokers compared with non-smokers. ${ }^{10}$ Additionally, independent of cigarette smoking $\mathrm{Cd}$ associates with coronary heart disease, peripheral vascular disease and chronic obstructive airway disease. ${ }^{10}$

Smoking is also a main environmental risk factor for anti-citrullinated protein antibody (ACPA)-positive RA. ${ }^{11}$ A landmark study has demonstrated that a combination of smoking and the presence of double copies of HLA-DR shared epitope genes increases the risk for ACPA-positive RA by 21-fold compared with the risk among non-smokers carrying no shared epitope genes. ${ }^{12}$ Underlying this important association, positive immunostaining for citrullinated proteins in smoker's bronchoalveolar lavage cells but not in those from non-smokers has been reported. ${ }^{12}$ Recently it was reported that $\mathrm{Cd}$, the component of cigarette smoke, may trigger citrullination of intracellular cytokeratins in the cultured human lung epithelial cells of A549 cell line. ${ }^{13}$

It has been demonstrated that serum Cd levels vary considerably depending on age, sex, socioeconomic status and smoking status. ${ }^{14}$ Therefore, case-control studies need to adjust for these demographic characteristics. Previous studies on the association between bodily Cd levels and RA are sparse. In most published studies on such association, the number of patients used was very low. In addition, important confounders listed above are not always accounted in such studies. Niedermeier and Griggs have compared Cd levels between RA synovial fluid samples $(\mathrm{n}=50)$ and cadaver synovial fluid samples $(n=50)$ and found that RA synovial fluid samples have lower Cd levels, although serum Cd levels in patients with RA $(\mathrm{n}=105)$ are similar to those in controls $(\mathrm{n}=105){ }^{15}$ However, their study did not account for age, smoking history or socioeconomic status in terms of matching cases and controls. Pedersen and Christensen have analysed concentrations of $\mathrm{Cd}$ in serum, urine and sweat in patients with RA and control subjects matched for age, sex, smoking habit and drinking habit. ${ }^{16}$ No significant differences in bodily Cd levels were noted. ${ }^{16}$ However, only 10 patients with RA were used in their study ${ }^{16}$ Further studies by Afridi et al have been reported. ${ }^{17-19}$ Their initial study reported on 53 Irish patients with RA ( $51 \%$ males) and 52 control cases (52\% males) broadly matched for age, smoking history and occupation. They found significantly higher $\mathrm{Cd}$ and lead $(\mathrm{Pb})$ levels in scalp hair in both smoking and non-smoking patients with RA compared with their respective controls. In both male and female RA smokers and non-smokers, Cd levels were threefold higher than their respective controls. ${ }^{17} \mathrm{~A}$ further study of RA scalp hair samples $(n=78)$ reported that mean values of $\mathrm{Cd}$ and $\mathrm{Pb}$ were significantly $(\mathrm{p}<0.001$, respectively) higher in patients with RA (both smokers and non-smokers) than those in controls $(n=82)$ matched for age and sex whereas concentration of zinc ( $\mathrm{Zn})$ was lower in patients with RA. ${ }^{18}$ Afridi et al have also demonstrated that mean values of arsenic (As), Cd, mercury $(\mathrm{Hg})$ and $\mathrm{Pb}$ are significantly higher in scalp hair and serum samples of patients with RA ( $\mathrm{n}=53)$ compared with healthy controls $(n=52)$ whereas $\mathrm{Zn}$, copper $(\mathrm{Cu})$, manganese $(\mathrm{Mn})$ and selenium concentrations are found to be lower in patients with RA. ${ }^{19}$ The difference was significant in case of RA smokers $(p<0.001)$. Blood Cd levels were 1.6-fold higher in patients with RA (smokers and non-smokers) compared with their respective controls. ${ }^{19}$

A study on Pakistani patients with RA $(n=200)$ and control individuals $(n=200)$ has also observed significant differences between patients with RA and healthy control individuals for serum $\mathrm{Pb}, \mathrm{Cd}$, chromium $(\mathrm{Cr})$ and Nickel (Ni) levels $(\mathrm{p}<0.01) .{ }^{20}$ Overall, $\mathrm{Pb}, \mathrm{Cd}$ and $\mathrm{Cr}$ levels were 2.6, 6.2 and 11.8-fold higher while Ni levels were 2.73-fold lower in patients with RA than those in controls. However, their RA cases and controls were not matched for age, smoking history or socioeconomic status. There were no significant differences in serum metal levels between male and female patients with RA either. ${ }^{20}$ Thus, it is important to determine whether increased serum levels of $\mathrm{Cd}$ and other heavy metal levels in comparison with controls are associated with RA after adjusting for appropriate sociodemographic factors known to influence serum Cd levels such as age, sex, socioeconomic status and smoking status. Given that $\mathrm{Cd}$ may contribute to a high risk of developing RA as described above, our a priori hypothesis is that high serum Cd levels associate with an increased prevalence of RA. Accordingly, the objective of this study was to determine whether an increased RA prevalence was associated specifically with raised serum levels of $\mathrm{Cd}$ rather than increased bodily levels of other heavy metals through analysis of an established cohort of individuals with recorded heavy metal levels.

\section{METHODS}

We performed a cross-sectional study using the Korean National Health and Nutrition Examination Survey (KNHANES) data from 2008 to 2013 when heavy metal data were collected to evaluate the association between heavy metals and RA prevalence.

\section{Data source and ethical considerations}

The KNHANES is a national health and nutrition survey to identify health-vulnerable groups for policy prioritisation by identifying current statuses and trends of the public health and nutrition status. It is a national statistical project that has been carried out since 1998 based on the National Health Promotion Act. The Korean CDC (KCDC) provides raw data of KNHANES at its homepage (https://knhanes.cdc.go.kr). It also provided analysis guidelines so that weighting process can be appropriately performed for each variable. Written informed consent 
Table 1 Baseline characteristics of three populations of Korean National Health and Nutrition Examination Survey (KNHANES) in heavy metal measurement

\begin{tabular}{|c|c|c|c|}
\hline & Group 1 & Group 2 & Group 3 \\
\hline Study duration (year) & 2008-2012 & 2008-2009 & 2010 \\
\hline Measured metals & Serums $\mathrm{Cd}, \mathrm{Pb}$ and $\mathrm{Hg}$ & Urine As and serum Mn & Serum Zn \\
\hline Subjects (n) & 45811 & 20277 & 8958 \\
\hline $\begin{array}{l}\text { Patients with rheumatoid arthritis } \\
\text { (RA) versus control (n) }\end{array}$ & 693 vs 31522 & 330 vs 13998 & 133 vs 6119 \\
\hline Estimated prevalence of RA (\%) & $1.59(95 \% \mathrm{Cl} 1.31$ to 1.94$)$ & $2.00(95 \% \mathrm{Cl} 1.54$ to 2.60$)$ & 1.29 (95\% Cl 1.15 to 1.45$)$ \\
\hline Estimated population size & 41308759 & 36990119 & 43955210 \\
\hline
\end{tabular}

was obtained from all participants since 1998. Since 2008, data have been collected to assess the effects of exposure to heavy metals in the environment. The data source was deidentified and opened to the public. The study was approved by Seoul National University Hospital and College of Medicine in Seoul National University (Institutional Review Board No: 1803-010-925).

\section{Participants}

All participants included in the survey with heavy metal or mineral measurement were included for analysis. We defined patients with RA as having a physician diagnosis of RA in interview results of KNHANES data. Control subjects were defined as individuals who denied the diagnosis of RA made by a physician in the questionnaire. Heavy metals or minerals were measured in different time periods of the survey programme which resulted in three different data sets for analysis: $\mathrm{Cd}, \mathrm{Hg}$ and $\mathrm{Pb}$ from 2008 to 2012 survey (RA=693vs control=31522; group $1, \mathrm{n}=45811$ ); serum Mn and urine As from 2008 to 2009 survey (RA=330vs control=13998; group 2, n=20277); and serum Zn from 2010 survey ( $\mathrm{RA}=133$ vs control=6119; group 3, $\mathrm{n}=8958$ ).

\section{Measurements}

Serum $\mathrm{Cd}, \mathrm{Pb}$ and $\mathrm{Mn}$ levels were measured by graphite furnace atomic absorption spectrometry (PerkinElmer Analyst 600, PerkinElmer, Finland). Serum Hg levels were measured by gold amalgamation (DMA-80, Milestone, Italy). Urine As levels were measured by atomic absorption spectrometry adjusted by creatinine. ${ }^{21}$ Serum Zn levels were measured by inductively coupled plasma mass spectrometry (ICP/MS; PerkinElmer ICP-MS, USA).

Smoking status was determined based on two definitions. First, based on the WHO definition, smokers are those who have smoked 100 cigarettes or more in their whole life. Second, current smokers are considered for those who are currently smoking and have smoked 100 cigarettes or more in their whole life. We used the WHO definition of smokers to evaluate the effects of serums $\mathrm{Cd}$, $\mathrm{Pb}, \mathrm{Hg}, \mathrm{Mn}$ and $\mathrm{Zn}$. The second definition of smokers was used for urine As due to the short half-life of As.

\section{Statistical analysis}

We investigated the characteristics of three KNHANES survey populations with regard to heavy metal measurements. The prevalence and $95 \% \mathrm{CI}$ of RA were calculated for each population. Associations between serum heavy metal or mineral levels and prevalence of RA were evaluated using a general linear model considering complex sample design after adjusting for age, sex and smoking status. We included missing data values in the model as a categorical variable to calculate adjusted ORs as stated in the analysis guideline provided by the KCDC. Using a logistic regression model, we calculated ORs and 95\% CIs for increases of $1 \mu \mathrm{g} / \mathrm{L}$ in serum level of $\mathrm{Cd}$ and $\mathrm{Hg}, 1 \mu \mathrm{g}$ / $\mathrm{dL}$ in serum level of $\mathrm{Pb}$ and $\mathrm{Mn}$, and $1 \mu \mathrm{g} / \mathrm{L}$ creatinine urine As contributing to prevalent RA after adjusting for age, sex and smoking status. All statistical analyses were two sided and $p$ value $<0.05$ was considered statistically

Table 2 Demographic features of patients with RA and controls analysed by complex sample design

\begin{tabular}{|c|c|c|c|c|c|c|}
\hline & \multicolumn{2}{|l|}{ Group 1} & \multicolumn{2}{|l|}{ Group 2} & \multicolumn{2}{|l|}{ Group 3} \\
\hline & RA & Control & RA & Control & RA & Control \\
\hline Age (years) & $56.15 \pm 1.41$ & $44.90 \pm 0.21$ & $57.90 \pm 1.80$ & $44.69 \pm 0.23$ & $53.24 \pm 3.46$ & $44.57 \pm 0.53$ \\
\hline Sex, female (\%) & $76.87 \pm 3.85$ & $50.19 \pm 0.40$ & $78.21 \pm 5.00$ & $50.00 \pm 5.16$ & $77.93 \pm 8.60$ & $49.90 \pm 0.93$ \\
\hline Body weight (kg) & $60.12 \pm 0.99$ & $63.97 \pm 0.14$ & $60.22 \pm 1.16$ & $63.64 \pm 0.20$ & $57.49 \pm 2.10$ & $64.27 \pm 0.33$ \\
\hline Height $(\mathrm{cm})$ & $158.86 \pm 0.79$ & $163.98 \pm 0.11$ & $157.52 \pm 1.06$ & $163.82 \pm 0.14$ & $159.80 \pm 1.54$ & $164.20 \pm 0.26$ \\
\hline Body mass index $\left(\mathrm{kg} / \mathrm{m}^{2}\right)$ & $23.75 \pm 0.30$ & $23.70 \pm 0.04$ & $24.18 \pm 0.31$ & $23.63 \pm 0.06$ & $22.50 \pm 0.75$ & $23.77 \pm 0.11$ \\
\hline Smoking, WHO definition (\%) & $27.08 \pm 4.27$ & $42.64 \pm 0.50$ & $21.52 \pm 5.04$ & $42.66 \pm 0.73$ & $32.17 \pm 9.90$ & $44.18 \pm 1.04$ \\
\hline Current smoking (\%) & $13.94 \pm 3.02$ & $32.35 \pm 0.52$ & $21.52 \pm 5.04$ & $42.66 \pm 0.73$ & $14.25 \pm 7.54$ & $27.96 \pm 1.08$ \\
\hline
\end{tabular}

$\mathrm{RA}$, rheumatoid arthritis. 
Table 3 Estimated means of serum and urine heavy metal levels between patients with RA and controls analysed by complex sample design

\begin{tabular}{llrrr}
\hline & & RA & Control & P value \\
\hline Group 1 & Serum Cd $(\mu \mathrm{g} / \mathrm{L})$ & $1.30 \pm 0.07$ & $1.17 \pm 0.01$ & $<0.01$ \\
& Serum Pb $(\mu \mathrm{g} / \mathrm{dL})$ & $2.38 \pm 0.07$ & $2.44 \pm 0.02$ & 0.51 \\
& Serum Hg $(\mu \mathrm{g} / \mathrm{L})$ & $4.70 \pm 0.26$ & $4.85 \pm 0.06$ & 0.82 \\
Group 2 & Serum $\mathrm{Mn}(\mu \mathrm{g} / \mathrm{dL})$ & $1.29 \pm 0.04$ & $1.34 \pm 0.01$ & 0.26 \\
& Urine As $(\mu \mathrm{g} / \mathrm{L})$ creatinine & $143.90 \pm 14.16$ & $154.07 \pm 3.51$ & 0.49 \\
Group 3 & Serum Zn $(\mu \mathrm{g} / \mathrm{dL})$ & $131.42 \pm 4.53$ & $134.94 \pm 1.70$ & 0.54 \\
\hline
\end{tabular}

All serum and urine heavy metal levels were adjusted by age, sex, socioeconomic status and smoking status (serums $\mathrm{Cd}, \mathrm{Pb}, \mathrm{Hg}, \mathrm{Mn}$ and $\mathrm{Zn}$ by WHO definition of smoking, urine As by definition of current smoking).

The WHO definition of smoking: those who have smoked 100 cigarettes or more in their whole life. Definition of current smoking: those who are currently smoking and have smoked 100 cigarettes or more in their whole life.

RA, rheumatoid arthritis.

significant. All analyses were performed using IBM SPSS V.22 (IBM) or Stata software V.13.0 (StataCorp).

\section{Patient and public involvement}

The KNHANES data were released after anonymisation. The study population was not involved in the design of this study.

\section{RESULTS}

The estimated population size with complex sample design analysis was 41308759 from 2008 to 2012 (group 1). In this population, the prevalence of RA was $1.59 \%$
(95\% CI 1.31 to 1.94 , table 1$)$. Table 2 shows demographic features of patients with RA and controls.

Serum Cdlevelswere higher in patients with RA than those in the control (RA vs control; $1.30 \pm 0.07$ vs $1.17 \pm 0.01 \mu \mathrm{g} / \mathrm{L}$, $\mathrm{p}<0.01)$. However, there were no significant differences in serum $\mathrm{Pb}$ level $(2.38 \pm 0.07$ vs $2.44 \pm 0.02 \mu \mathrm{g} / \mathrm{dL}, \mathrm{p}=0.51)$, serum $\mathrm{Hg}$ level $(4.70 \pm 0.26$ vs $4.85 \pm 0.06 \mu \mathrm{g} / \mathrm{L}, \mathrm{p}=0.82)$, serum Mn level $(1.29 \pm 0.04$ vs $1.34 \pm 0.01 \mu \mathrm{g} / \mathrm{dL}, \mathrm{p}=0.26)$, serum Zn level $(131.42 \pm 4.53$ vs $134.94 \pm 1.70 \mu \mathrm{g} / \mathrm{dL}$, $\mathrm{p}=0.54$ ) or urine As level (AAS, Atomic Absorption Spectroscopy; $143.90 \pm 14.16$ vs $154.07 \pm 3.51 \mu \mathrm{g} / \mathrm{L}$ creatinine, $\mathrm{p}=0.49$ ) between patients with RA and controls (table 3 ).

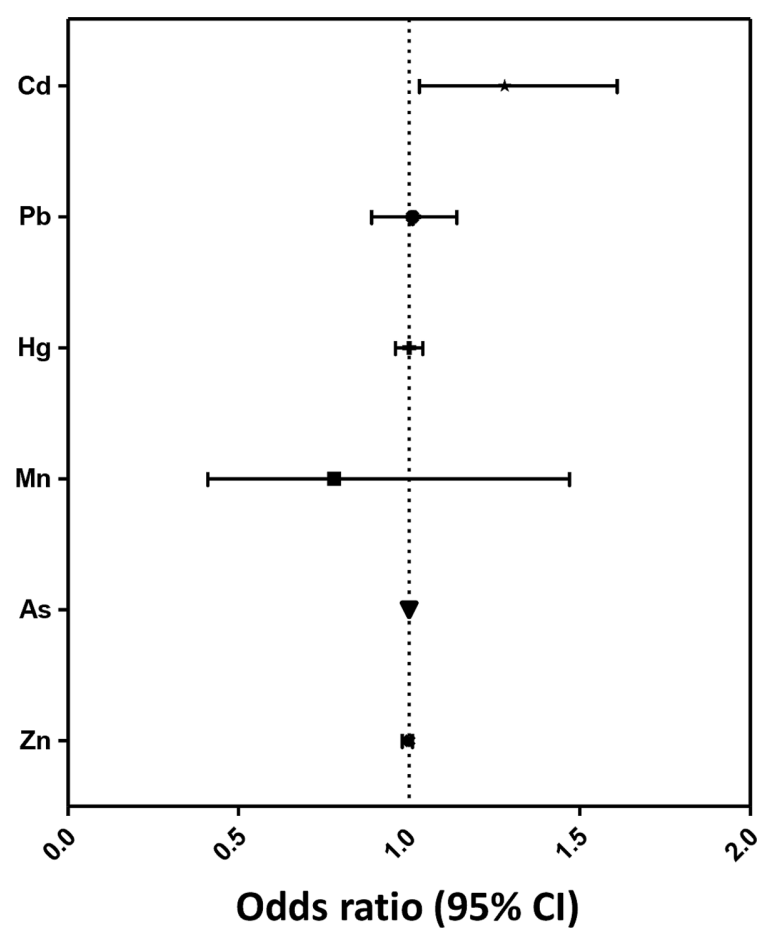

\begin{tabular}{|c|c|c|c|c|}
\hline & & OR & \multicolumn{2}{|c|}{$95 \%$ Cl } \\
\hline \multirow{2}{*}{ Group 1 } & Cd, serum & 1.28 & 1.03 & 1.61 \\
\cline { 2 - 5 } & Pb, serum & 1.01 & 0.89 & 1.14 \\
\cline { 2 - 5 } & Hg, serum & 1.00 & 0.96 & 1.04 \\
\hline \multirow{2}{*}{ Group 2 } & Mn, serum & 0.78 & 0.41 & 1.47 \\
\cline { 2 - 5 } & As, urine & 1.00 & 1.00 & 1.00 \\
\hline \multirow{2}{*}{ Group 3 } & Zn, serum & 1.00 & 0.98 & 1.01 \\
\hline
\end{tabular}

Figure 1 ORs $(95 \% \mathrm{Cl})$ of rheumatoid arthritis $(\mathrm{RA})$ prevalence according to serum $\mathrm{Cd}, \mathrm{Pb}$ and $\mathrm{Hg}$ levels with logistic regression model of complex sample design. ORs of RA prevalence according to increase of $1 \mu \mathrm{g} / \mathrm{L}$ for serums Cd and $\mathrm{Hg}$, increase of $1 \mu \mathrm{g} / \mathrm{dL}$ for serums $\mathrm{Pb}, \mathrm{Mn}$ and $\mathrm{Zn}$ and increase of $1 \mu \mathrm{g} / \mathrm{dL}$ creatinine for urine As were determined. All serum and urine heavy metal levels were adjusted by age, sex, socioeconomic status and smoking status (serums $\mathrm{Cd}, \mathrm{Pb}, \mathrm{Hg}, \mathrm{Mn}$ and $\mathrm{Zn}$ by the WHO definition of smoking, urine As by the definition for current smoking). 


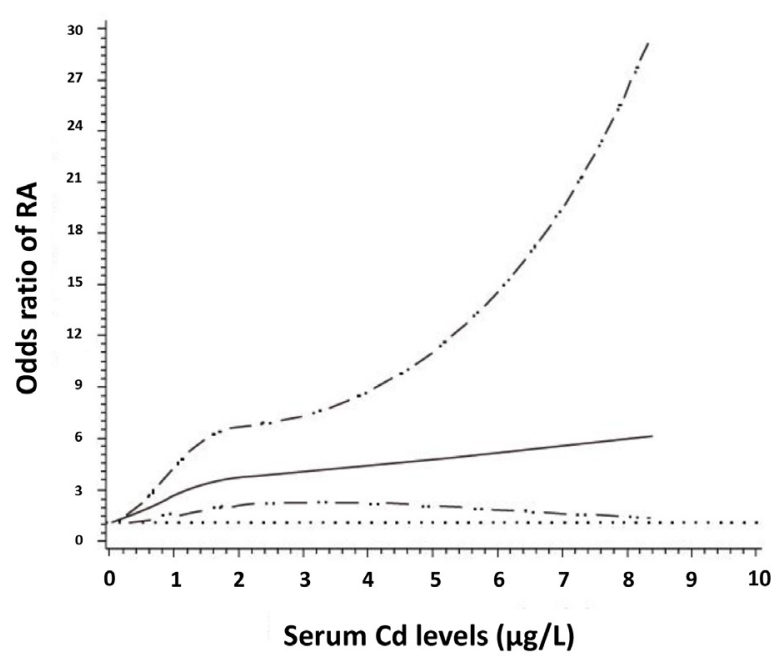

Figure 2 The cubic spline curve of the rheumatoid arthritis (RA) prevalence ORs by cadmium concentration was adjusted by age, sex and smoking. The solid line represents RA prevalence OR which increases as cadmium concentration increases. The broken line with double dots represents $95 \% \mathrm{Cl}$ widening with increase in the cadmium level. The dotted line represents level of prevalence OR identical to 1, above which the lower limit of $95 \% \mathrm{Cl}$ remains throughout the observed cadmium level.

ORs $(95 \% \mathrm{CI})$ of RA prevalence according to increase of $1 \mu \mathrm{g} / \mathrm{L}$ of serums $\mathrm{Cd}$ and $\mathrm{Hg}$ were 1.28 (95\% CI 1.03 to $1.61)$ and 1.00 (95\% CI 0.96 to 1.04$)$, respectively. With increase of $1 \mu \mathrm{g} / \mathrm{dL}$ of serums $\mathrm{Pb}$ and $\mathrm{Mn}$, ORs (95\% CI) of RA prevalence were 1.01 (95\% CI 0.89 to 1.14 ) and 0.78 (95\% CI 0.41 to 1.47), respectively. According to urine As increase of $1 \mu \mathrm{g} / \mathrm{L}$ creatinine, OR (95\% CI) of RA prevalence was 1.00 (95\% CI 0.998 to 1.001 ) (figure 1 ). The cubic spline curve of RA prevalence ORs adjusted for age, sex and smoking status showed an increased risk of RA prevalence according to increase in serum Cd (figure 2).

Serum Cd levels stratified by gender were not significantly different between RA and controls. However, female patients with RA tended to have higher Cd levels compared with female controls (RA vs control: $1.49 \pm 0.09 \mu \mathrm{g} / \mathrm{L}$ vs $1.34 \pm 0.02 \mu \mathrm{g} / \mathrm{L}, \mathrm{p}=0.14)$. The OR of $\mathrm{RA}$ prevalence according to an increase in serum Cd level of $1 \mu \mathrm{g} / \mathrm{L}$ showed a significant increased risk of RA prevalence only in female patients (male: 0.86 (95\% CI 0.41 to 1.81 ), female: 1.33 (95\% CI 1.06 to 1.66$)$ ). There was a striking increase in the prevalence of RA in women with increasing quartiles of Cd levels, showing a 19-fold difference in female RA prevalence between individuals in the lowest quartile of $\mathrm{Cd}$ level and those in the highest quartile $(0.18 \%$ vs $3.42 \%)$ (figure 3$)$.

\section{DISCUSSION}

RA is believed to develop as a result of induction of post-translational protein modifications (PTM) such as acetylation, citrullination and carbamylation with subsequent autoantibody response. ${ }^{22} \mathrm{Cd}$ may play a key role in

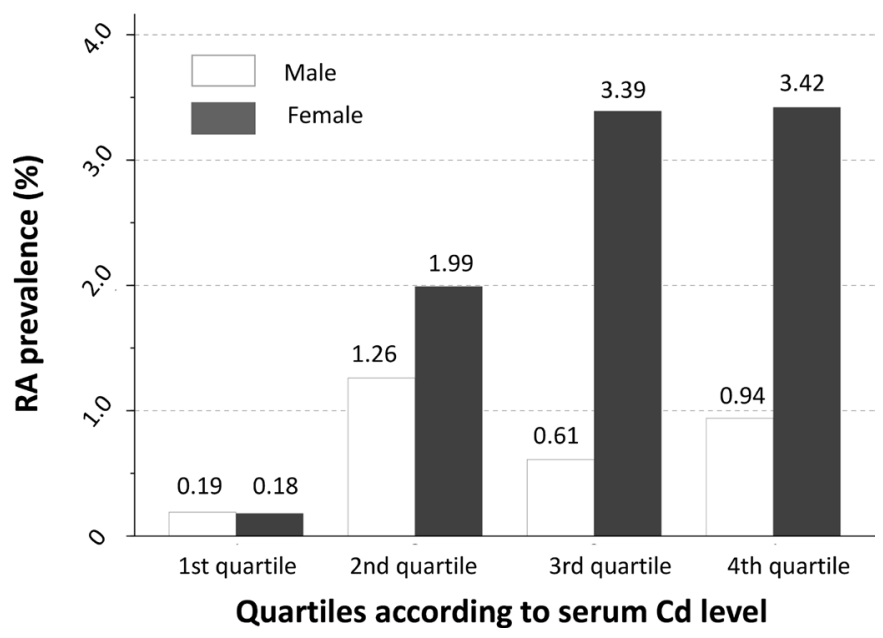

Figure 3 The prevalence of rheumatoid arthritis (RA) according to quartiles of serum cadmium level.

all three of these post-translational modifications. When proteins are exposed to $\mathrm{Cd}$, acetylation ${ }^{23}$ and citrullination ${ }^{13}$ have been reported. Cyanate carbamylated protein lysine residues and cyanate formation via a myeloperoxidase (MPO)-catalysed oxidation of thiocyanate derived from cigarette smoke have been reported. ${ }^{24}$ Systemic Cd administration can significantly elevate MPO activity in rat lungs. ${ }^{25}$ Given that $\mathrm{Cd}$ and thiocyanate are both components of cigarette smoke, it is conceivable that MPO and thiocyanate generated in the lungs of smokers might carbamylate in situ proteins.

Proinflammatory properties of $\mathrm{Cd}$ include upregulation of nuclear factor- $\kappa \mathrm{B}$ and activator protein 1 transcription factors, cytokines (interleukin (IL)-6, tumour necrosis factor- $\alpha$, IL, IL-8), macrophage inflammatory protein 2 chemokine, MPO, inducible nitric oxide synthase, matrix metalloproteinases, cyclooxygenase 2 (COX-2) enzymes, prostaglandin E2, adhesion molecules (intercellular adhesion molecule 1 , vascular cell adhesion molecule 1 and platelet/endothelial cell adhesion molecule 1) and C-reactive protein. ${ }^{26}$ However, there are contradictory findings reported in the literature on anti-inflammatory factors associated with $\mathrm{Cd}$ exposure such as downregulation of proinflammatory genes (COX-2 and CXCL2 chemokine). ${ }^{27}$ Likewise, there are conflicting results on Cd exposure and inflammatory process in RA. Two studies have suggested that low doses of $\mathrm{Cd}$ might have beneficial effect on joint inflammation in animals. ${ }^{89}$ However, Cd at higher doses exacerbates joint inflammation. ${ }^{8}$

\section{Principal findings of the study}

Our study showed that serum Cd levels were increased in patients with RA compared with those in the control group $(1.30 \pm 0.07$ vs $1.17 \pm 0.01 \mu \mathrm{g} / \mathrm{L}, \mathrm{p}<0.01)$. Our results also revealed that the risk of RA prevalence was exponential. The OR (95\% CI) of RA prevalence according to serum Cd increase of $1 \mu \mathrm{g} / \mathrm{L}$ was 1.28 (95\% CI 1.03 to 1.61) (figure 1). We described changes in OR according to serum Cd levels using cubic spline curve (figure 2). The cubic spline curve provided an intuitive understanding 
of the linear increase in RA risk with a dose-response relationship.

The geometric mean of serum Cd levels in the third KNHANES performed in 2005 has been reported to be $1.53 \mu \mathrm{g} / \mathrm{L}(95 \%$ CI 1.48 to 1.58$) .{ }^{28}$ Blood Cd levels can change with demographic and lifestyle factors including smoking. However, geometric means of blood Cd levels for non-smoking general population did not exceed $2 \mu \mathrm{g} / \mathrm{L} .{ }^{29}$ Figure 2 demonstrated that the slope was steeper at Cd levels less than $1.5 \mu \mathrm{g} / \mathrm{L}$ where serum levels of the healthy general population would have been better represented. Furthermore, ORs for RA prevalence increased according to low serum Cd concentrations throughout the toxic range of serum Cd levels. It can be concluded that high levels of $\mathrm{Cd}$ can increase the risk of RA appreciably in women independent of smoking. These results can be reconciled with animal data suggesting that low levels of $\mathrm{Cd}$ could be protective ${ }^{89}$ while high levels exacerbate disease. ${ }^{8}$ However, the OR of RA prevalence according to an increase in serum Cd level of $1 \mu \mathrm{g} / \mathrm{L}$ showed a significant increased risk of RA prevalence only in female patients (male: 0.86 (95\% CI 0.41 to 1.81 ), female: 1.33 (95\% CI 1.06 to 1.66)). In this study, Cd did not appear to be associated with RA prevalence in men. Diminished statistical power due to low prevalence of male RA (23\%) in group 1 RA cohort with only 159 RA men might have influenced results reported here. Additionally. RA men might not necessarily have high serum Cd levels to initiate their disease. Instead, they might have high lung Cd levels as a recent review of male patients with RA has highlighted that RA men have enhanced exposure to various dusts that act as absorbers of $\mathrm{Cd}$ derived from cigarette smoke and that the Cd is trapped in the lung to initiate RA. ${ }^{30}$

\section{Unanswered questions and future research}

Further studies with much larger cohorts of RA men taking occupation of male patients with RA into account are needed. It is also important to study those unexposed to various dusts to determine if they have raised serum $\mathrm{Cd}$ levels in the future. In the study reported here, we were not aware of occupations of patients with RA or controls.

\section{Strengths and weaknesses of this study}

We believe that the RA population studied here is representative of Korean RA population reported in the literature attending secondary care rheumatology outpatient clinics in terms of gender, age and smoking history. ${ }^{31} 32$ The autoantibody status of the patients with RA studied here is not known. However, given the potential for Cd to trigger antigen PTMs, it is possible that Cd is mainly associated with seropositive RA. It was noteworthy that the geometric mean of blood Cd level in the Korean population studied here was $1.17 \pm 0.01 \mu \mathrm{g} / \mathrm{L}$. This is much higher than blood Cd levels reported in Sweden (median blood $\mathrm{Cd}$ in men and women: $0.24 \mu \mathrm{g} / \mathrm{L}$ and $0.27 \mu \mathrm{g} / \mathrm{L}$, respectively) ${ }^{33}$ The prevalence of ACPA positivity is also different between RA cohorts in Korea $(87 \%)^{34}$ and
Sweden $(63 \%) .{ }^{12}$ Whether there are significant differences in blood Cd levels in the general populations of these two countries remains unclear. Further studies specifically investigating the relationship between seropositive RA and blood Cd will be of importance.

This study is unable to fully address the reasons why serum Cd levels are significantly increased in patients with RA. Although our results were adjusted for personal history of cigarette smoking, exposure to involuntary cigarette smoking was not accounted for here. A recent study has demonstrated an association between involuntary smoking exposure with urine cotinine level and blood $\mathrm{Cd}$ level in female Korean non-smoking population. ${ }^{35} \mathrm{It}$ is noteworthy that female non-smokers with exposure to secondhand cigarette smoke have significantly higher RA disease activity than female non-smokers without exposure to secondhand smoke. ${ }^{36}$ However, the studies investigating whether exposure to involuntary cigarette smoke is associated with RA have not been reported yet.

\section{Strengths and weaknesses in relation to other studies}

We were able to demonstrate a strikingly significant increase in the prevalence of RA in women with increasing quartiles of serum Cd levels, showing 19-fold difference in female RA prevalence between individuals in the lowest quartile of serum $\mathrm{Cd}$ level and those in the highest quartile $(0.18 \%$ vs $3.42 \%)$. Our study is the first study to account for environmental risk factors such as smoking, socioeconomic status, gender and age for variations in serum Cd levels when examining the relationship between raised serum Cd levels and RA prevalence. The prevalence of RA is somewhat higher than expected. We defined RA as a physician diagnosis of RA recorded as positive by the patients in their questionnaire. It is conceivable that patients with osteoarthritis or patients with RA with very mild disease (seronegative and not taking disease-modifying drugs) were included, however, this is likely to have weakened the association between RA prevalence and raised serum Cd levels given the plausible association between $\mathrm{Cd}$ and seropositive RA.

Our findings could not be explained by an increased smoking frequency in female patients with RA as smoking prevalence (ever having smoked) in the RA cohort was $27 \%$, which was strikingly lower than that in the respective controls (42.6\%). Furthermore, serum Cd levels were not significantly higher in female RA smokers compared with those in female controls (data not shown). Therefore, the risk factors other than smoking might account for the increased prevalence of RA in those females with serum Cd levels in the highest quartile.

\section{Possible explanations and implications for clinicians and policymakers}

A recent study on Malaysian RA women who rarely smoke has demonstrated an increased risk of RA (OR $2.8,95 \%$ CI 1.6 to 5.2 ) associated with working in the textile industry. ${ }^{37}$ However, this finding might have been confounded by exposure to $\mathrm{Cd}$ as the textile industry has 
used $\mathrm{Cd}$ in dyes to colour textiles. ${ }^{5}$ Most other occupations associated with $\mathrm{RA}^{38}{ }^{39}$ also have the potential to predispose individuals to $\mathrm{Cd}$ inhalation and raise serum Cd levels. However, most of these occupations are relevant to men. Recently, a case-control study has demonstrated an increased risk of male ACPA-positive RA among bricklayers and concrete workers (OR 2.9, 95\% CI 1.4 to 5.7) and this association is independent of confounders such as smoking or silica exposure. ${ }^{40}$ Cement dust exposure is associated with significantly raised serum Cd levels in Nigerian cement workers (twofold increase) compared with controls. However, female and male residents living in close proximity to the cement factory have 90-fold higher serum Cd levels than controls, exemplifying the fact that women can have markedly raised Cd levels with indirect exposure to toxic substances usually associated with male orientated occupations. ${ }^{40}$

Increased serum Cd levels can occur as the consequence of diet. In a Japanese study, Cd levels in diets are significantly $(\mathrm{p}<0.01)$ correlated with blood $\mathrm{Cd}$ levels when results from examinees of the same survey region are pooled and compared in terms of geometric means. ${ }^{41}$ Furthermore, Cd absorption is enhanced with iron deficiency. ${ }^{42}$ It is well known that patients with RA commonly have iron deficiency. ${ }^{43} 44$ Rambod et al have demonstrated a number of significant differences between the diets of patients with RA and control subjects and it is possible that the significant differences in Cd levels reported here in the patients with RA could represent differences in diets and this would be subject to further research. ${ }^{45}$

\section{Unanswered questions and future research}

In view of the above, further studies are needed to determine if occupations, exposure to secondhand cigarette smoke, area of residency (living in close proximity to relevant industries and main roads), diet and iron deficiency are associated with raised serum $\mathrm{Cd}$ levels in patients with RA. In this study, there was no significant association between RA and serum levels of metals ( $\mathrm{Pb}, \mathrm{Hg}, \mathrm{Mn}$ and $\mathrm{Zn})$ or urine As level. Therefore, metals per se do not appear to be associated with RA. Cd might have very specific pathological properties that predispose individuals to RA when they are exposed to this metal. Metal $\mathrm{Cu}$ has consistently been observed to be associated with RA. A meta-analysis has demonstrated that serum levels of $\mathrm{Cu}$ in Caucasian patients with RA are significantly higher than those in Asian patients with RA. ${ }^{46}$ RA disease activity has been observed in those living in places where farm soils contain high levels of $\mathrm{Cu} .{ }^{47}$ Recently, it has been demonstrated that the induction of protein citrullination and ACPA generation in an animal model exposed to Ni nanomaterials. ${ }^{48}$ Further studies are needed to determine if other metals are also associated with RA.

In conclusion, our results showed that serum Cd level was significantly increased in patients with RA and OR of female RA prevalence was increased according to serum Cd concentration. These findings add substantial evidence to the concern that increased exposure to $\mathrm{Cd}$ is an RA risk factor in the general population.

\section{Author affiliations}

${ }^{1}$ Division of Rheumatology, Department of Internal Medicine, Seoul National University Hospital, Seoul, Korea

${ }^{2}$ Division of Clinical Epidemiology, Medical Research Collaborating Center, Biomedical Research Institute, Seoul National University Hospital, Seoul, Korea ${ }^{3}$ Rheumatology Department, Royal Cornwall Hospital, Truro, UK

${ }^{4}$ Rheumatology Department, University of Exeter Medical School, Truro, UK ${ }^{5}$ Department of Molecular Medicine and Biopharmaceutical Sciences, Graduate School of Convergence Science and Technology, College of Medicine, Medical Research Center, Seoul National University, Seoul, Korea

Contributors SHJ, DH, JYL and YWS designed this study and wrote the manuscript. YWS obtained funding. SHJ and JYL analysed the data. All authors have full access to all data (including statistical reports and tables) used in the study and take responsibility for the integrity of the data and accuracy of the data analysis. YWS acts as the guarantor.

Funding This study was supported by a grant (HI14C1277) from the Korea Health Technology R\&D Project through the Korea Health Industry Development Institute (KHIDI) funded by the Ministry of Health and Welfare, Republic of Korea. It was also supported by a grant (NRF-2015M3A9B6052011) from the National Research Foundation funded by the Ministry of Science, ICT and Future Planning, Republic of Korea. Cornwall Arthrits Trust also provided funding.

Disclaimer The funders played no role in the study design, data collection, data analysis, data interpretation, writing of this report or the decision to submit this article for publication.

Competing interests None declared.

Patient consent for publication Not required.

Ethics approval Institutional Review Board of Seoul National University Hospital and College of Medicine in Seoul National University (IRB No 1803-010-925).

Provenance and peer review Not commissioned; externally peer reviewed. Data sharing statement No additional data available.

Open access This is an open access article distributed in accordance with the Creative Commons Attribution Non Commercial (CC BY-NC 4.0) license, which permits others to distribute, remix, adapt, build upon this work non-commercially, and license their derivative works on different terms, provided the original work is properly cited, appropriate credit is given, any changes made indicated, and the use is non-commercial. See: http://creativecommons.org/licenses/by-nc/4.0/.

\section{REFERENCES}

1. World Health Organization. Expert Committee on Rheumatic Diseases, First Report, 1954. Annals of the rheumatic diseases 1954;13:253-4.

2. Kwon JM, Rhee J, Ku H, et al. Socioeconomic and employment status of patients with rheumatoid arthritis in Korea. Epidemiol Health 2012;34:e2012003.

3. Oh IH, Yoon SJ, Seo HY, et al. The economic burden of musculoskeletal disease in Korea: a cross sectional study. BMC Musculoskelet Disord 2011;12:157.

4. Hutchinson D. Cadmium, one of the villains behind the curtain: has exposure to cadmium helped to pull the strings of seropositive rheumatoid arthritis pathogenesis all along? Int $J$ Rheum Dis 2015;18:570-3.

5. Murphy D, Mathew A, James B, et al. Could the inhalation of cadmium and other metals in addition to textile dust inhalation account for the observed increased risk of rheumatoid arthritis in textile workers? Ann Rheum Dis 2016;75:e30.

6. Murphy D, James B, Hutchinson D. Could the significantly increased risk of rheumatoid arthritis reported in Italian male steel workers be explained by occupational exposure to cadmium? J Occup Med Toxicol 2016;11.

7. Murphy D, Hutchinson D. Cadmium, road dust and rheumatoid arthritis: an alternative hypothesis to general air pollution. J Inflamm $2015 ; 12$. 
8. Ansari MM, Khan HA. Effect of cadmium chloride exposure during the induction of collagen induced arthritis. Chem Biol Interact 2015;238:55-65.

9. Bonaventura P, Courbon G, Lamboux A, et al. Protective effect of low dose intra-articular cadmium on inflammation and joint destruction in arthritis. Sci Rep 2017;7:2415.

10. Bernhard D, Rossmann A, Wick G. Metals in cigarette smoke. IUBMB Life 2005;57:805-9.

11. Stolt P, Bengtsson C, Nordmark B, et al. Quantification of the influence of cigarette smoking on rheumatoid arthritis: results from a population based case-control study, using incident cases. Ann Rheum Dis 2003;62:835-41.

12. Klareskog L, Stolt $\mathrm{P}$, Lundberg $\mathrm{K}$, et al. A new model for an etiology of rheumatoid arthritis: smoking may trigger HLA-DR (shared epitope)-restricted immune reactions to autoantigens modified by citrullination. Arthritis Rheum 2006;54:38-46.

13. Hutchinson D, Müller J, McCarthy JE, et al. Cadmium nanoparticles citrullinate cytokeratins within lung epithelial cells: cadmium as a potential cause of citrullination in chronic obstructive pulmonary disease. Int J Chron Obstruct Pulmon Dis 2018;13:441-9.

14. Moon S-W, Gwak J-I, Park Y-H. The Effect of Smoking and Second-Hand Smoking on the Concentration of Mercury, Lead and Cadmium in the Blood: Based on the Fifth Korea National Health and Nutrition Examination Survey. Korean Journal of Family Practice 2016;6:44-8.

15. Niedermeier W, Griggs JH. Trace metal composition of synovial fluid and blood serum of patients with rheumatoid arthritis. J Chronic Dis 1971:23:527-36.

16. Pedersen LM, Christensen JM. Chromium, nickel and cadmium in biological fluids in patients with rheumatoid arthritis compared to healthy controls. Acta Pharmacol Toxicol 1986;59 Suppl 7:392-5.

17. Afridi HI, Kazi TG, Brabazon D, et al. Association between essential trace and toxic elements in scalp hair samples of smokers rheumatoid arthritis subjects. Sci Total Environ 2011;412413:93-100.

18. Afridi HI, Kazi TG, Brabazon D, et al. Interaction between zinc, cadmium, and lead in scalp hair samples of Pakistani and Irish smokers rheumatoid arthritis subjects in relation to controls. Biol Trace Elem Res 2012;148:139-47.

19. Afridi HI, Kazi TG, Talpur FN, et al. Relationship between toxic metals exposure via cigarette smoking and rheumatoid arthritis. Clin Lab 2014;60:1735-45.

20. Irfan S, Rani A, Riaz N, et al. Comparative Evaluation of Heavy Metals in Patients with Rheumatoid Arthritis and Healthy Control in Pakistani Population. Iran J Public Health 2017;46:626-33.

21. Hulanicki A, Bulska E, Wrobel K. Calibration and Reference Samples in Trace Metals Determination in Serum by Graphite Furnace Atomic Absorption Spectrometry. Analytical Sciences 1992;8:405-9.

22. Trouw LA, Rispens T, Toes REM. Beyond citrullination: other posttranslational protein modifications in rheumatoid arthritis. Nat Rev Rheumatol 2017;13:331-9.

23. Gzyl J, Chmielowska-Bąk J, Przymusiński R, et al. Cadmium affects microtubule organization and post-translational modifications of tubulin in seedlings of soybean (Glycine max L.). Front Plant Sci 2015;6.

24. Wang Z, Nicholls SJ, Rodriguez ER, et al. Protein carbamylation links inflammation, smoking, uremia and atherogenesis. Nat Med 2007;13:1176-84.

25. Kataranovski M, Mirkov I, Belij S, et al. Lungs: remote inflammatory target of systemic cadmium administration in rats. Environ Toxicol Pharmacol 2009;28:225-31.

26. Olszowski T, Gutowska I, Baranowska-Bosiacka I, et al. Cadmium Alters the Concentration of Fatty Acids in THP-1 Macrophages. Biol Trace Elem Res 2018;182:29-36.

27. Bernhard D, Rossmann A, Henderson B, et al. Increased serum cadmium and strontium levels in young smokers: effects on arterial endothelial cell gene transcription. Arterioscler Thromb Vasc Biol 2006;26:833-8.
28. Kim NS, Lee BK. National estimates of blood lead, cadmium, and mercury levels in the Korean general adult population. Int Arch Occup Environ Health 2011;84:53-63.

29. Pocock SJ, Delves HT, Ashby D, et al. Blood cadmium concentrations in the general population of British middle-aged men. Hum Toxicol 1988;7:95-103

30. Tellez-Plaza M, Navas-Acien A, Crainiceanu CM, et al. Cadmium and peripheral arterial disease: gender differences in the 1999-2004 US National Health and Nutrition Examination Survey. Am J Epidemiol 2010;172:671-81.

31. Hur JW, Choe JY, Kim DW, et al. Rheumatoid arthritis patients fulfilling Korean National Health Insurance reimbursement guidelines for anti-tumor necrosis factor- $\alpha$ treatment and comparison to other guidelines. Rheumatol Int 2015;35:1817-23.

32. Boo S, Froelicher ES, Yun JH, et al. Perceived and actual risk of cardiovascular disease in patients with rheumatoid arthritis in Korea: a cross-sectional study. Medicine 2016;95:e5117.

33. Borné $\mathrm{Y}$, Barregard L, Persson M, et al. Cadmium exposure and incidence of heart failure and atrial fibrillation: a population-based prospective cohort study. BMJ Open 2015;5:e007366-e66.

34. Fisher BA, Bang SY, Chowdhury M, et al. Smoking, the HLA-DRB1 shared epitope and ACPA fine-specificity in Koreans with rheumatoid arthritis: evidence for more than one pathogenic pathway linking smoking to disease. Ann Rheum Dis 2014;73:741-7.

35. Jung SY, Kim S, Lee K, et al. Association between secondhand smoke exposure and blood lead and cadmium concentration in community dwelling women: the fifth Korea National Health and Nutrition Examination Survey (2010-2012). BMJ Open 2015;5:e008218.

36. Hammam N, Gheita TA. Impact of secondhand smoking on disease activity in women with rheumatoid arthritis. Clin Rheumatol 2017;36:2415-20.

37. Too CL, Muhamad NA, Ilar A, et al. MyEIRA Study Group. Occupational exposure to textile dust increases the risk of rheumatoid arthritis: results from a Malaysian population-based case-control study. Ann Rheum Dis 2016;75:997-1002.

38. Murphy $D$, Hutchinson D. Is male rheumatoid arthritis an occupational disease? A Review. Open Rheumatol J 2017:11:88-105.

39. Ilar A, Alfredsson L, Wiebert P, et al. Occupation and risk of developing rheumatoid arthritis: results from a population-based case-control study. Arthritis Care Res 2018;70:499-509.

40. Richard EE, Augusta Chinyere NA, Jeremaiah OS, et al. Cement dust exposure and perturbations in some elements and lung and liver functions of cement factory workers. J Toxicol 2016;2016:1-7.

41. Watanabe $\mathrm{T}$, Koizumi A, Fujita $\mathrm{H}$, et al. Dietary cadmium intakes of farmers in nonpolluted areas in Japan, and the relation with blood cadmium levels. Environ Res 1985;37:33-43.

42. Flanagan PR, McLellan JS, Haist J, et al. Increased dietary cadmium absorption in mice and human subjects with iron deficiency. Gastroenterology 1978;74(5 Pt 1):841-6.

43. Wilson A, Yu HT, Goodnough LT, et al. Prevalence and outcomes of anemia in rheumatoid arthritis: a systematic review of the literature. Am J Med 2004;116 Suppl 7A(Suppl 7A):50-7.

44. Hansen TM, Hansen NE, Birgens HS, et al. Serum ferritin and the assessment of iron deficiency in rheumatoid arthritis. Scand $J$ Rheumatol 1983;12:353-9.

45. Rambod M, Nazarinia M, Raieskarimian F. The impact of dietary habits on the pathogenesis of rheumatoid arthritis: a case-contro study. Clin Rheumatol 2018;37:2643-8.

46. Xin L, Yang X, Cai G, et al. Serum Levels of Copper and Zinc in Patients with Rheumatoid Arthritis: a Meta-analysis. Biol Trace Elem Res 2015;168:1-10.

47. Yang TH, Yuan TH, Hwang YH, et al. Increased inflammation in rheumatoid arthritis patients living where farm soils contain high levels of copper. J Formos Med Assoc 2016;115:991-6.

48. Mohamed BM, Boyle NT, Schinwald A, et al. Induction of protein citrullination and auto-antibodies production in murine exposed to nickel nanomaterials. Sci Rep 2018;8:679. 